\title{
Acute pancreatitis as an uncommon complication of hydatid cyst of the liver: A case report and systematic literature review
}

\author{
Ahmed Ben Mahmoud $^{\text {a,b, }}$, Souhaib Atri ${ }^{\text {a,b }}$, Wael Rebai ${ }^{\text {a,b }}$, Houcine Maghrebi ${ }^{\text {a,b }}$, \\ Amine Makni ${ }^{\mathrm{a}, \mathrm{b}}$, Montasser Jameleddine Kacem ${ }^{\mathrm{a}, \mathrm{b}}$ \\ a Department of Surgery "A”, La Rabta Hospital, Tunis, Tunisia \\ ${ }^{\mathrm{b}}$ Faculty of Medicine of Tunisia, Tunis El Manar University, Tunis, Tunisia
}

\section{A R T I C L E I N F O}

\section{Keywords:}

Hydatid cyst

Acute pancreatitis

Cysto-biliary fistula

Case report

\begin{abstract}
A B S T R A C T
Hydatid disease is a major health problem worldwide. The liver is the most frequent location of hydatid disease. Acute pancreatitis secondary to liver hydatid cyst ruptured in the biliary tract is scarce and fewly described in literature. The management of this pancreatic complication of liver hydatid disease is challenging and includes a combination of surgical and endoscopic approaches. We report herein a rare case of hydatid cyst of the liver with cysto-biliary communication revealed by acute pancreatitis. A systematic literature review of similar cases reported was provided to compare surgical and endoscopic techniques.

A thirty-year-old woman was referred to our emergency unit for acute pancreatitis. The CT-scan findings revealed a liver hydatid cyst ruptured in the biliary tract and daughter vesicles within were found, responsible for C-grade acute pancreatitis. We decided then to perform an emergency surgery through a bisoucostal incision. We performed a cholecystectomy and a peroperative cholangiogram that showed the communication between the cyst and left biliary tracts and the presence of daughter vesicle within the common bile duct. We conducted an exploration of the common bile duct with extraction of vesicle daughters. We left behind a T-tube in the common bile duct and we sutured the cysto-biliary fistula. Drainage was left in the remnant cavity after unroofing the cyst. Postoperative course was uneventful. Six months follow-up showed no recurrence.

Cysto-biliary communication of liver hydatid disease revealed by acute pancreatitis is uncommon. We chose to perform emergency open surgery. However, through a systematic literature review, we noticed that endoscopic treatment is an efficient therapeutic and diagnostic tool to delay a morbid surgery of the liver and the common bile duct.
\end{abstract}

\section{Introduction}

Hydatid disease is an endemic zoonosis in the Mediterranean area. It can reach any organ of the abdomen especially the liver and the lungs, more scarcely the pancreas. Regarding the hydatid cyst of the liver, numerous complications are reported in the literature such as infection, the rupture in the biliary tract, or in the abdominal cavity. However, acute pancreatitis is a fewly known complication of hydatid cysts arising from the liver. We report herein the challenging management of an unusual case of a thirty-year-old-woman who was treated in our surgery department for an acute pancreatitis revealing a hydatid cyst of the liver ruptured in the biliary tract. We reviewed and summarized in Table 1 the management of reported cases of acute pancreatitis complicating hydatid cyst of the liver as indicated in the English literature. Among 32 papers, seven were excluded from review for data unavailability. The work has been reported in line with the SCARE criteria [1].

\section{Presentation of case}

It was a thirty-year-old woman, with no remarkable medical history, living in a sheep-farming area, who came to our emergency unit for epigastric pain and persisting vomiting associated with fever and chills evolving for four days. The pain was very intense and unbearable, radiating towards the back. The patient didn't complain of any abdominal pain or transit disorders before. No hydatid disease was known within her family.

The physical examination revealed a conscious woman despite an altered condition. She had a fever $\left(39{ }^{\circ} \mathrm{C}\right)$ without jaundice.

\footnotetext{
* Corresponding author. Department of Surgery "A”, La Rabta Hospital, La Rabta Jebbari, 1007, Tunis, Tunisia.

E-mail address: ahmed.benmahmoud92@gmail.com (A. Ben Mahmoud).
} 
Cardiovascular examination showed tachycardia but normal blood pressure $(120 / 75 \mathrm{mmHg})$. The respiratory rate was normal. The abdominal examination was characterized by an epigastric guarding associated with tenderness in the right hypochondria. No abdominal mass was palpated. The rest of the examination showed no other abnormalities.
Laboratory tests revealed a biological inflammatory syndrome consisting of high leucocyte count $(20,500 \mathrm{UI} / \mathrm{ml})$ and c - reactive protein level $(60 \mathrm{mg} / \mathrm{l})$. Additionally, investigations showed abnormal liver tests such as five times normal limits transaminases and high bilirubin levels predominantly direct (Total Bilirubin/Direct Bilirubin: 25/21 mg/1). Furthermore, Serum Lipase levels were frankly high (4700 U/L with

Table 1

\begin{tabular}{|c|c|c|c|c|c|c|c|}
\hline References & Year & Country & Journal & $\begin{array}{l}\text { Number of } \\
\text { cases }\end{array}$ & $\begin{array}{l}\text { Age (Average } \\
\text { Age) }\end{array}$ & $\begin{array}{l}\text { Sex }(\operatorname{sex} \\
\text { ratio } \mathrm{F} / \mathrm{H})\end{array}$ & Treatment \\
\hline${ }^{*}$ Mestiri et al. [9] & 1982 & Tunisia & Med Chir Dig. & 3 & - & - & - \\
\hline $\begin{array}{l}{ }^{*} \text { Braithwaite et al. } \\
\text { [11] }\end{array}$ & 1983 & - & Med J Aust & - & - & - & - \\
\hline $\begin{array}{l}{ }^{*} \text { Hammad et al. } \\
\text { [10] }\end{array}$ & 1985 & Algeria & Am J Surg & 4 & - & - & - \\
\hline $\begin{array}{l}{ }^{*} \text { Agorogiannis et al. } \\
\text { [8] }\end{array}$ & 1989 & Greece & - & 12 & - & - & - \\
\hline $\begin{array}{l}{ }^{*} \text { Salgarello et al. } \\
\text { [13] }\end{array}$ & 1989 & - & G Chir & - & - & - & - \\
\hline${ }^{q}$ Fodha et al. [14] & 1989 & Tunisia & Tunis. Med & - & - & - & - \\
\hline Medina et al. [15] & 1990 & Spain & REV ESP ENFERM DIG & 1 & 29 & $\mathrm{~F}$ & $\begin{array}{l}\text { Endoscopy (ERCP + Hydatid membrane } \\
\text { extraction) }+ \text { Elective Surgery }\end{array}$ \\
\hline Mentes et al. [16] & 1990 & Turkey & Jpn. J. Surg. & 1 & 56 & M & Elective Surgery \\
\hline Parthé et al. [17] & 1994 & Germany & Dtsch.med.Wschr & 1 & 47 & $\mathrm{~F}$ & Endoscopy (nasocyst drainage) \\
\hline El Idrissi et al. [18] & 1996 & Morocco & Presse Med & 1 & 30 & $\mathrm{~F}$ & Elective Surgery \\
\hline \multirow[t]{2}{*}{ Aydin et al. [19] } & 1997 & Turkey & Euro.J.Gastro.Hepato & 2 & 22 & $\mathrm{~F}$ & $\begin{array}{l}\text { Elective Surgery (choledocotomy }+ \\
\text { cystotomy) }\end{array}$ \\
\hline & & & & & 17 & $\mathrm{~F}$ & Elective Surgery (Pericystectomy) \\
\hline${ }^{7}$ Wong et al. [12] & 1999 & United Kingdom & J R Coll Surg Edinb & 1 & $\mathrm{~N} / \mathrm{A}$ & $\mathrm{N} / \mathrm{A}$ & $\mathrm{N} / \mathrm{A}$ \\
\hline \multirow[t]{3}{*}{$\begin{array}{l}\text { Sàez-Royuela et al. } \\
\text { [20] }\end{array}$} & 1999 & Spain & $\begin{array}{l}\text { Gastrointestinal } \\
\text { endoscopy }\end{array}$ & 3 & 26 & M & $\begin{array}{l}\text { Endoscopy (ERCP + Hydatid membrane } \\
\text { extraction) }\end{array}$ \\
\hline & & & & & 74 & $\mathrm{~F}$ & $\begin{array}{l}\text { Endoscopy (ERCP + Hydatid membrane } \\
\text { extraction) }\end{array}$ \\
\hline & & & & & 81 & $\mathrm{~F}$ & $\begin{array}{l}\text { Endoscopy (ERCP + Hydatid membrane } \\
\text { extraction) }\end{array}$ \\
\hline Bellara et al. [21] & 2004 & Tunisia & Annales de chirurgie & 1 & 40 & $\mathrm{~F}$ & Elective Surgery \\
\hline Al-Toma et al. [22] & 2004 & $\begin{array}{l}\text { Netherlands } \\
\text { (Turkish) }\end{array}$ & $\begin{array}{l}\text { European journal of } \\
\text { internal medicine }\end{array}$ & 1 & 50 & M & $\begin{array}{l}\text { Endoscopy (ERCP + Hydatid membrane } \\
\text { extraction) }+ \text { Elective surgery }\end{array}$ \\
\hline Sciumé et al. [23] & 2005 & Italy & Ann. Ital. Chir. & 1 & 18 & $\mathrm{~F}$ & $\begin{array}{l}\text { Endoscopy (ERCP + Hydatid membrane } \\
\text { extraction) }\end{array}$ \\
\hline \multirow[t]{2}{*}{ Beltsis et al. [24] } & 2005 & Greece & $\begin{array}{l}\text { Annals of } \\
\text { Gastroenterology }\end{array}$ & 2 & 16 & $\mathrm{~F}$ & $\begin{array}{l}\text { Endoscopy (ERCP + Hydatid membrane } \\
\text { extraction) }\end{array}$ \\
\hline & & & & & 21 & $\mathrm{~F}$ & $\begin{array}{l}\text { Endoscopy (ERCP + Hydatid membrane } \\
\text { extraction) }\end{array}$ \\
\hline Arifuddin et al. [25] & 2006 & USA (Greek) & J.Clin.Gastroenterol & 1 & 63 & M & $\begin{array}{l}\text { Endoscopy (ERCP + Hydatid membrane } \\
\text { extraction) }\end{array}$ \\
\hline Ghidirim et al. [26] & 2006 & Moldavia & Chirurgia & 1 & 17 & M & $\begin{array}{l}\text { Endoscopy (ERCP + Hydatid membrane } \\
\text { extraction) }+ \text { Emergency Surgery }\end{array}$ \\
\hline \multirow[t]{2}{*}{ Angel et al. [27] } & 2008 & & REV ESP ENFERM DIG & 2 & 18 & $\mathrm{~F}$ & Elective Surgery \\
\hline & & & & & 73 & M & Elective Surgery \\
\hline $\begin{array}{l}\text { Katsinelos et al. } \\
\text { [28] }\end{array}$ & 2009 & Greece & Cases Journal & 1 & 31 & M & $\begin{array}{l}\text { Endoscopy (ERCP + Hydatid membrane } \\
\text { extraction) }+ \text { Elective surgery }\end{array}$ \\
\hline $\begin{array}{l}\text { Rodríguez-Sicilia } \\
\text { et al. [29] }\end{array}$ & 2012 & Spain (Morocco) & REV ESP ENFERM DIG & 1 & 37 & M & Elective Surgery \\
\hline Cakır et al. [30] & 2012 & Turkey & Turkiye Parazitol Derg & 1 & 60 & M & $\begin{array}{l}\text { Endoscopy (ERCP }+ \text { Hydatid membrane } \\
\text { extraction) }\end{array}$ \\
\hline $\begin{array}{l}\text { Ozcaglayan et al. } \\
\text { [31] }\end{array}$ & 2014 & Turkey & JBR-BTR & 1 & 37 & M & N/A \\
\hline $\begin{array}{l}\text { Chaudhary et al. } \\
\text { [32] }\end{array}$ & 2013 & India & $\begin{array}{l}\text { Tropical } \\
\text { Gastroenterology }\end{array}$ & 1 & 35 & M & $\begin{array}{l}\text { Endoscopy (ERCP + Hydatid membrane } \\
\text { extraction) }+ \text { Biliary Stent }\end{array}$ \\
\hline Kitchens et al. [33] & 2014 & USA & J Gastrointest Surg & 1 & 71 & M & Elective Surgery \\
\hline Belkouch et al. [34] & 2014 & Morocco & $\begin{array}{l}\text { Pan African Medical } \\
\text { Journal }\end{array}$ & 1 & 49 & M & $\begin{array}{l}\text { Endoscopy (ERCP + Hydatid membrane } \\
\text { extraction) }\end{array}$ \\
\hline $\begin{array}{l}\text { Mahmoudi et al. } \\
\text { [35] }\end{array}$ & 2015 & Tunisia & $\begin{array}{l}\text { Pan African Medical } \\
\text { Journal }\end{array}$ & 1 & 41 & M & Emergency Surgery \\
\hline Sikar et al. [36] & 2017 & Turkey & $\begin{array}{l}\text { Ulus Travma Acil Cerrahi } \\
\text { Derg }\end{array}$ & 1 & 49 & M & Emergency Surgery \\
\hline Ahmad et al. [37] & 2018 & Pakistan & J Pak Med Assoc & 1 & 40 & M & $\begin{array}{l}\text { Endoscopy (ERCP }+ \text { Hydatid membrane } \\
\text { extraction) }+ \text { Stent }+ \text { Elective Surgery }\end{array}$ \\
\hline $\begin{array}{l}\text { Bendjaballah et al. } \\
\text { [38] }\end{array}$ & 2019 & Algeria & Ann Clin & 1 & 46 & $\mathrm{~F}$ & $\begin{array}{l}\text { Endoscopy (ERCP + Hydatid membrane } \\
\text { extraction) }\end{array}$ \\
\hline $\begin{array}{l}\text { Lahmidani et al. } \\
\text { [39] }\end{array}$ & 2013-2019 & Morocco & $\begin{array}{l}\text { Pan African Medical } \\
\text { Journal }\end{array}$ & 16 & $(44.33)$ & 1.3 & $\begin{array}{l}\text { Endoscopic evacuation of membranes } \\
(87.5 \%) \\
\text { Surgery } 100 \%\end{array}$ \\
\hline
\end{tabular}


normal laboratory unit range: $40-80 \mathrm{U} / \mathrm{L}$ ).

The diagnosis of acute pancreatitis was set taking into consideration typical abdominal pain associated with above-three times normal level serum lipase.

We decided then to perform an abdominal ultrasound since gallbladder stones are the most commonly reported etiology of acute pancreatitis in our country. It showed a thin walled gallbladder without any calculus objectified. However, intra and extrahepatic biliary tracts were dilated but no intraluminal abnormalities were seen. In addition, a multilocular $10 \mathrm{~cm}$ cystic mass was noticed in the left liver suggesting the presence of a type III hydatid cyst of the liver.

Consequently, an abdominal CT-Scan was mandatory thereby determining the features and relationships of the liver mass, all the more so as we were at this point suspecting a twice as complicated hydatid cyst. CT scan showed then a ten-centimeter multilocular cystic mass arising from the fourth and third segments of the liver. A communication between the mass and left intra-hepatic biliary tract was objectified, resulting in dilatation of the common bile duct and the left bile ducts ahead. However, no intraluminal hydatid material nor stones were seen, but a heterogonous content. In addition, a peripancreatic inflammation was revealed setting the diagnosis of $\mathrm{C}$ grade acute pancreatitis (CT severity index) (Fig. 1).

Through a bi-subcostal incision, we found a $10 \mathrm{~cm}$-hydatid cyst arising from the left liver (Fig. $2 \mathrm{~A}$ ).

Firstly, we took down the left and right triangular ligaments followed by cholecystectomy. Then, we performed an intraoperative cholangiography via a transcystic drainage that showed a dilated common bile duct and left intra-hepatic ducts. In addition, no contrast agent passed in the duodenum suggesting the presence of an obstacle of the common bile duct. Furthermore, it revealed a fistula communicating the cyst to left biliary ducts (Fig. 3A + B).

Subsequently, the puncture-aspiration of the cyst brought bile content. For this reason, we didn't use a scolicidal agent in the cystic cavity to avoid secondary biliary cirrhosis. A large cystobiliary fistula of $1 \mathrm{~cm}$ was revealed. Hence, Common bile duct exploration was conducted. Many vesicle daughters were retrieved (Fig. 2 B). After abundant lavage, choledecoscopy allowed us to check that the common bile duct was cleared of all cystic content. The cyst wall being soft, we chose to suture the large bilio-cystic fistula and to leave behind drainage in the remnant cavity and a T-tube in the common bile duct.

The post-operative course was uneventful. A postoperative cholangiogram on the 5th day was normal. No leakage was noticed (Fig. 2C). The Patient was discharged on day 7 after the removal of intra-cavitary drainage. T-drainage was removed after three weeks without any incident. 6 months follow-up showed no complication or recurrence.

\section{Discussion}

Hydatid disease is a worldwide zoonosis caused by the larval stage of the Echinococcus parasite. It represents a public health problem in endemic areas like in Tunisia [2]. Although hydatid cysts can reach any organ of the human body, the liver is the most commonly affected organ [3]. Hydatid cysts of the liver are usually asymptomatic. However, some patients may become symptomatic due to complicated hydatid disease. In fact, Hydatid cysts of the liver may be complicated by infection, anaphylactic shock, compression of adjacent organs or rupture in the peritoneal cavity or biliary tract. Among all these complications, cysto-biliary communication is the most frequent one [4], leading, in some cases, to life-threatening cholangitis or cyst infection. However, acute pancreatitis is a little-known complication of hydatid disease. The primary pancreatic location of hydatid cyst actually represents less than $1 \%$ of all cases reported in the literature $[5,6]$. It is responsible for a few cases of acute pancreatitis by cyst compression or migrated vesicle daughters' obstruction of the main pancreatic duct [7]. Nevertheless, in our case, a cyst emerging from the liver has caused acute pancreatitis. In this case report, the pancreatic disease is related to the obstruction of the pancreatic duct by migrated parasite through the common bile duct. It implies accordingly the presence of a cysto-biliary communication. Almost all the well-documented reports of this rare complication are case reports.

Through a systematic Pubmed search, using the keywords "acute pancreatitis" and "liver hydatid cyst" and "hydatid pancreatitis", we found 32 published articles dealing with the subject. We excluded 7 articles [8-14] that could not be opened. We decided then to review 25 papers [15-39]reporting 45 cases. The data has been analyzed using Excel. All the cases are summarized in Table 1. The main limitation of our analysis is that some cases lack important informations.

The mean age of the patients was 42 years with a range of $16-81$. The ratio of women to men was 0.48 . Primary surgical treatment was performed in 11 patients, two of which were done in emergency cases. The treatment consisted in cystotomy or total pericystectomy without major liver resection. The common bile duct was explored and cysto-biliary communication was sutured in all cases. ERCP was a therapeutic alternative in 33 cases. Among these 33 cases, 12 patients hasn't undergone surgery for the hydatid cysts whereas 21 had elective surgery. Emergency surgery was performed after endoscopic treatment in only one case. Nasocyst drainage was needed in one case and intrabiliary stent was put in 2 cases.

The symptoms weren't specific and we couldn't distinguish the hydatid cyst of the liver from other etiologies of acute pancreatitis at physical examination or patients' blood tests. Serology could be suggestive of the hydatid origin of acute pancreatitis, but it is rarely made in emergency cases like in our patient. The diagnosis is hence set by either Ultrasonography or CT-scan. Ultrasonography is mainly made to clarify

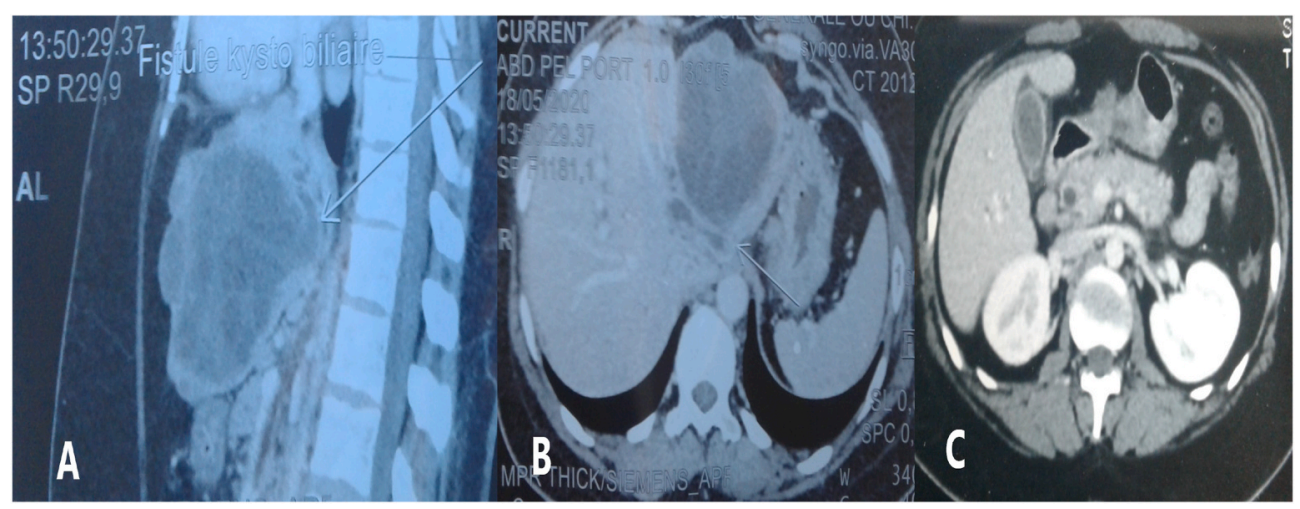

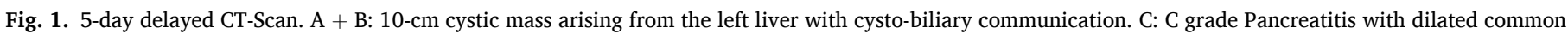
bile duct. We decided then to perform an urgent open surgery for a hydatid cyst doubly complicated of rupture in biliary tracts and acute pancreatitis. 


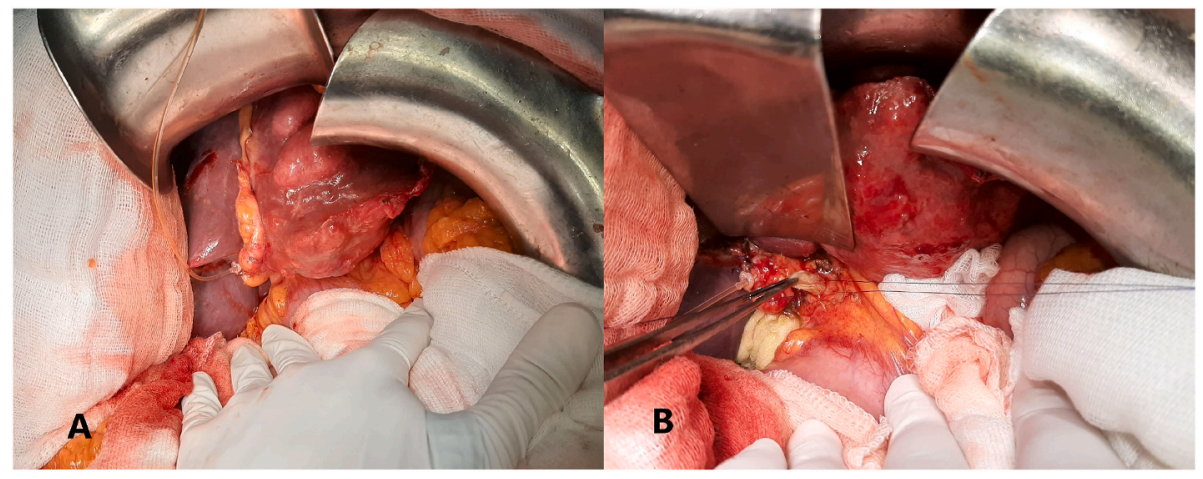

Fig. 2. Per operative view. A: Hydatid cyst of the left liver. B: Common bile duct exploration and vesicle daughters' extraction.

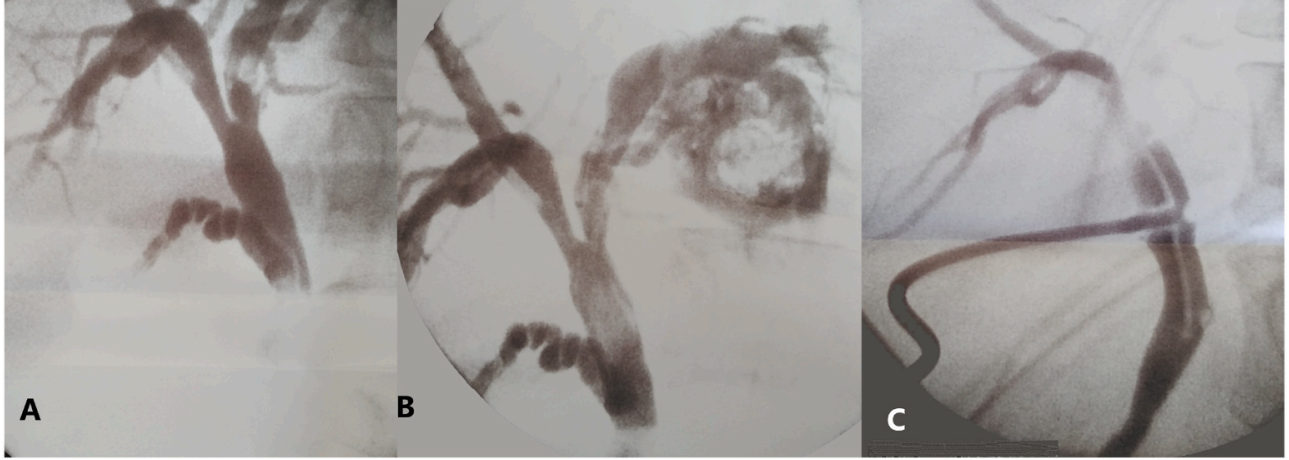

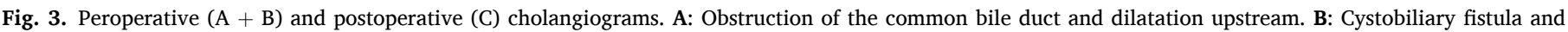
opacification of the cystic cavity. C: Normal cholangiogram.

the etiology of acute pancreatitis. It is well-known that gallstones are the first etiology of pancreatitis. However, Ultrasonography is sufficient for the diagnosis of hydatid disease of the liver [40] but remains inadequate to assign it to the pancreatic disorder. In our case, Ultrasonography permitted us to suspect a hydatid cyst of the liver but we couldn't confirm it's liability in the pancreatitis etiopathogenesis. 5-days delayed CT scan is mandatory to identify the prognostic stage of acute pancreatitis and it was made in all the 45 cases reported in the literature. Furthermore, CT-scan could provide evidence of cysto-biliary communication or migrated daughter vesicles in the biliary tract, which is responsible for the occurrence of acute pancreatitis.

Open surgery for hydatid cysts ruptured in the biliary tracts remains the standard treatment. The general principles in treating hydatid cysts are applicable in the case of acute pancreatitis. The aim of surgery is to treat the cyst, the remnant cavity, the cystobiliary communication and to ensure the vacuity of the common bile duct by clearing the hydatid material. The procedure generally begins with the protection of the peritoneal cavity with scolicidal agents followed by the aspiration of the cyst content. We do not inject scolicidal agents in the cystic cavity in case of bilious content to prevent secondary biliary cirrhosis. Intraoperative cholangiography is performed to identify biliary fistula. Two methods [41] are commonly used to deal with hydatid cysts of the liver: A radical method consisting in total pericystectomy with the clearance of common bile duct and insertion of T-tube Kehr. A hepatectomy can also be performed but it is known to be a morbid procedure for such a benign disease. However, conservative surgery is the most commonly performed procedure and different techniques are described for the treatment of biliary fistula according to their diameter. Cystotomy or partial pericystectomy and simple suturing of the fistula with drainage of the common bile duct using Kehr drain are reserved to fistulas less than $5 \mathrm{~mm}$.On the other hand, for larger fistulas we can perform a trans-fistula oddien drainage (DITFO), biliary kysto-disconnection according to Perdromo, and bipolar drainage [4]. In our case, we decided to perform a bipolar drainage because of the efficiency and time-saving of this technique especially in case of emergency. Through the literature review, we found that 34 patients underwent open surgery, including emergency situations or delayed after ERCP and sphincterotomy, permitting the evacuation of membranes. Lahmidani et al. [39] reported 16 cases of hydatid acute pancreatitis. In this case series, all patients had ERCP permitting the evacuation of hydatid membranes in $81.25 \%$ of cases. All the patients underwent open surgery to treat definitively the cystic echinococcosis of the liver.

The main complication of liver hydatid disease surgery is biliary leakage that can lead to reoperation in some cases. The suppuration of the residual cavity is common and can be prevented by omentopolasty and capitonnage [41]. Anaphylactic shock is rare but described in few reports. However, postoperative course are usually uneventful like in our case.

ERCP with sphincterotomy is a promising diagnostic and therapeutic tool [20]. It permits to set the diagnosis of cystobiliary communication, evacuate hydatid material and eventually put a stent if the vacuity of the common bile duct is not assured. The endoscopic procedure is most commonly used in cases of obstructive jaundice or acute cholangitis. Furthermore, a postoperative ERCP is helpful for residual hydatid membranes left in the common bile duct. It is also useful for high anesthesia risk patients. In addition, endoscopic therapy can delay urgent and morbid surgery after sedation of the acute pancreatitis episode. However, Ghidirim et al. [26] reported a case of a 17-year old man who presented with an acute pancreatitis due to cysto-biliary communication of a hydatid cyst of the liver. He was treated with primary ERCP and extraction of hydatid membranes. Nevertheless, emergency surgery was mandatory two weeks later because of a new episode of hydatid rupture occurred with clinical presentation of cholangitis. This case report highlights the fact that radical or conservative surgical treatments of the 
cyst remain the only procedures aiming to eradicate the disease especially in low-income countries where ERCP is not affordable and hydatid disease is very common.

\section{Conclusion}

Hydatid disease of the liver and cysto-biliary communication is a well-known pathology especially in endemic areas. However, the migration of hydatid material is may scarcely be a causal factor of acute pancreatitis. The treatment of this kind of complication is challenging. Open surgery is the standard treatment in emergency or elective cases. Nevertheless, we recommend considering ERCP with sphincterotomy as a therapeutic and diagnostic tool in order to delay morbid surgery of the liver and the common bile duct.

\section{Ethical approval}

Not applicable.

\section{Funding sources}

None.

\section{Author contribution}

Amine Makni: Performed the surgery and reviewed the article. Ahmed Ben Mahmoud: Article writing and literature review. Souhaib Atri: Article writing and literature review. Wael Rebai: Analyzed and interpreted patient's data. Houcine Maghrebi: Analyzed and interpreted patient's data. Montasser Jameleddine Kacem: Article concept and review. All authors have read and approved the manuscript.

\section{Registration of research studies}

Not applicable.

\section{Guarantor}

Ahmed Ben Mahmoud.

\section{Consent}

Written informed consent was obtained from the patient for publication of this case report and accompanying images. A copy of the written consent is available for review by the Editor-in-Chief of this journal.

\section{Provenance and peer review}

Not commissioned, externally peer-reviewed.

\section{Declaration of competing interest}

The authors declare that they have no competing interests.

\section{Acknowledgements}

None.

\section{References}

[1] R.A. Agha, T. Franchi, C. Sohrabi, G. Mathew, A. Kerwan, A. Thoma, A.J. Beamish, A. Noureldin, A. Rao, B. Vasudevan, B. Challacombe, B. Perakath, B. Kirshtein, B. Ekser, C.S. Pramesh, D.M. Laskin, D. Machado-Aranda, D. Miguel, D. Pagano, F, H. Millham, G. Roy, H. Kadioglu, I.J. Nixon, I. Mukhejree, J.A. McCaul, J. Chi-Yong Ngu, J. Albrecht, J.G. Rivas, K. Raveendran, L. Derbyshire, M.H. Ather, M.
A. Thorat, M. Valmasoni, M. Bashashati, M. Chalkoo, N.Z. Teo, N. Raison, O. J. Muensterer, P.J. Bradley, P. Goel, P.S. Pai, R.Y. Afifi, R.D. Rosin, R. Coppola, R. Klappenbach, R. Wynn, R.L. De Wilde, S. Surani, S. Giordano, S. Massarut, S. G. Raja, S. Basu, S.A. Enam, T.G. Manning, T. Cross, V.K. Karanth,

V. Kasivisvanathan, Z. Mei, The SCARE 2020 guideline: updating consensus surgical CAse REport (SCARE) guidelines, Int. J. Surg. (2020), https://doi.org/ 10.1016/j.ijsu.2020.10.034.

[2] S. Lahmar, W. Rebaï, B.S. Boufana, P.S. Craig, R. Ksantini, A. Daghfous, F. Chebbi, F. Fteriche, H. Bedioui, M. Jouini, M. Dhibi, A. Makni, M.S. Ayadi, A. Ammous, M. J. Kacem, Z. Ben Safta, Cystic echinococcosis in Tunisia: analysis of hydatid cysts that have been surgically removed from patients, Ann. Trop. Med. Parasitol. 103 (2009) 593-604, https://doi.org/10.1179/000349809X12502035776153.

[3] G. Nunnari, M.R. Pinzone, S. Gruttadauria, B.M. Celesia, G. Madeddu, G. Malaguarnera, P. Pavone, A. Cappellani, B. Cacopardo, Hepatic echinococcosis: clinical and therapeutic aspects, World J. Gastroenterol. 18 (2012) 1448-1458, https://doi.org/10.3748/wjg.v18.i13.1448.

[4] J.M. Ramia, J. Figueras, R. De La Plaza, J. García-Parreño, Cysto-biliary communication in liver hydatidosis, Langenbeck's Arch. Surg. 397 (2012) 881-887, https://doi.org/10.1007/s00423-012-0926-8.

[5] A. Makni, M. Jouini, M. Kacem, Z.B. Safta, Acute pancreatitis due to pancreatic hydatid cyst: a case report and review of the literature, World J. Emerg. Surg. 7 (2012) 7, https://doi.org/10.1186/1749-7922-7-7.

[6] C. Dziri, W. Dougaz, I. Bouasker, Surgery of the pancreatic cystic echinococcosis: systematic review, Transl. Gastroenterol. Hepatol. 2 (2017) 1-8, https://doi.org/ 10.21037/tgh.2017.11.13.

[7] A. Makni, M. Jouini, M. Kacem, Z. Ben Safta, Extra-hepatic intra-abdominal hydatid cyst: which characteristic, compared to the hepatic location? Updates Surg. 65 (2013) 25-33, https://doi.org/10.1007/s13304-012-0188-6.

[8] A. Agorogiannis, E. Naoum, G. Georgiadis, I. Evangelou, E. Grantzis, I. Agorogianni, Acute pancreatitis as a complication of intrabiliary rupture of hydatid cysts of the liver, in: Abstr. Second Mediterr. Surg. Congr. Athens, June 24th-27th, 1989, p. 193.

[9] S. Mestiri, M. Hadj Salah, R. Laarif, M. Kehila, Hepatic hydatid cyst opening into the bile ducts and acute pancreatitis: etiopathogenic problems apropos of 3 cases, Med. Chir. Dig. 11 (1982) 197-199.

[10] A. Hammad, B. Mentouri, Acute pancreatitis in Algeria. Report of 221 cases, Am. J. Surg. 149 (1985) 709-711, https://doi.org/10.1016/S0002-9610(85)80170-7.

[11] R.K.B.P.A. Braithwaite, Hepatic hydatid disease presenting as pancreatitis, Med. J. Aust. 2 (1983) 369-370.

[12] L.S. Wong, O. Braghirolli-Neto, M. Xu, J.A. Buckels, D.F. Mirza, Hydatid liver disease as a cause of recurrent pancreatitis, J. R. Coll. Surg. Edinb. 44 (1999) 407-409.

[13] G. Salgarello, P. Bruzzone, T. Salgarello, G.M. Giannatempo, G. Alcaro, D. De Vivo, G. La Vecchia, Invasione delle vie biliari da rottura di cisti idatidea e pancreatite acuta (Rupture of hydatid cyst with invasion of the bile ducts and acute pancreatitis), Geka Chiryo 10 (1989) 259-261.

[14] M. Fodha, N. Bel Hadj Bettaieb, A. Morjane, H. Hamza, H. Jegham, A. Letaief, Pancreatites aigues et kystes hydatiques du foie ouverts dans les voies bilaires. A propos d'un nouveau cas (Acute pancreatitis and hydatid cysts of the liver opening into the bile ducts. Apropos of a new case), Tunis. Med. 67 (1989) 201-205.

[15] E. Medina, E. Orti, P. Canelles, M.A. Calvo, E. Molina, Quiste hidatidico hepatico complicado y pancreatitis aguda. Valor de la CPRE y tratamiento con esfinterotomia endoscopica, Rev. Esp. Enferm. Dig. 78 (1990) 315-318.

[16] A.E. and O.O. Ali MENTES, Yficel BATUR,A Eldem, O Ozbal Pancreatitis as a Complication of a Hydatic Liver Cyst -A Case Report- Ali, JAPANESr J. SURGER. 20 (1990) 356-358. https://doi.org/10.1136/bmj.1.4281.114-b.

[17] S. Parthé, M. Maier, B. Kohler, S. Kress, J.F. Riemann, Akute Pankreatitis infolge Einbruchs einer Echinococcuszyste in das Gallengangssystem (Acute pancreatitis due to the rupture of an echinococcal cyst into the bile duct system), Dtsch. Med. Wochenschr. 119 (1994) 624-627, https://doi.org/10.1055/s-2008-1058739.

[18] H.D. el Idrissi, M. Ridai, N.O. Zerouali, Pancréatite d'origine hydatique (Pancreatitis of hydatid origin), Presse Med. 25 (1996) 2022-2024.

[19] A. Aydin, G. Ersöz, O. Tekesin, A. Mentes, Hydatid acute pancreatitis: a rare complication of hydatid liver disease. Report of two cases, Eur. J. Gastroenterol. Hepatol. (1997), https://doi.org/10.1097/00042737-199702000-00020.

[20] F. Saez-Royuela, L. Yuguero, A. Lopez-Morante, J.C. Perez-Alvarez, J.L. MartinLorente, C. Ojeda, Acute pancreatitis caused by hydatid membranes in the biliary tract: treatment with endoscopic sphincterotomy, Gastrointest. Endosc. 49 (1999) 793-796, https://doi.org/10.1016/S0016-5107(99)70305-6.

[21] I.L. Bellara, H. Amara, N. Hablani, L. Harzallah, D.B. Abbassi, C. Kraiem, Pancréatite aiguë d'origine hydatique: À propos d'un cas, Ann. Chir. 129 (2004) 372-375, https://doi.org/10.1016/j.anchir.2004.04.017.

[22] A.A. Al-Toma, R.J. Vermeijden, A. Van De Wiel, Acute pancreatitis complicating intrabiliary rupture of liver hydatid cyst, Eur. J. Intern. Med. 15 (2004) 65-67, https://doi.org/10.1016/j.ejim.2003.11.008.

[23] C. Sciumè, G. Geraci, F. Pisello, T. Facella, R. Vaglica, G. Modica, Acute pancreatitis during liver hydatidosis: treatment with ERCP and endoscopic sphincterotomy, Ann. Ital. Chir. 76 (2005) 491-494.

[24] A. Beltsis, G. Chatzimavroudis, A. Iliadis, I. Tsavdaridis, I. Vasiliadis, B. Papaziogas, P. Katsinelos, Intrabiliary rupture of hepatic hydatid cyst presenting as acute pancreatitis and treatment with endoscopic sphincterotomy: report of two cases, Ann. Gastroenterol. 18 (2005) 353-356.

[25] R. Arifuddin, M. Baichi, A. Ullah, B. Maliakkal, Cystic echinococcus - a rare presentation of acute biliary obstruction and pancreatitis, J. Clin. Gastroenterol. 40 (2006) 763-764, https://doi.org/10.1097/00004836-200609000-00020. 
[26] G.Z. Gh Ghidirim, I. Mişin, E. Guţu, I. Gagauz, A. Danci, M. Vozian, Intrabiliary rupture of the hydatic cyst complicated with acute pancreatitis, Chirurgia (Bucur.) 101 (2006) 429-432.

[27] E.S.C.J.M. Ramia Ángel, P. Veguillas, J.M.S.B. Redondo, y J.G.-P. Jofré, Unidad, cartas al Director pancreatitis aguda hidatídica, Rev. Esp. Enferm. Dig. 100 (2008) $1-2$.

[28] P. Katsinelos, G. Chatzimavroudis, K. Fasoulas, E. Kamperis, T. Katsinelos, S. Terzoudis, G. Kokonis, I. Patsis, Acute pancreatitis caused by impaction of hydatid membranes in the papilla of Vater: a case report, Cases J. 2 (2009) 1-4, https://doi.org/10.4076/1757-1626-2-7374.

[29] M.J. Rodríguez-Sicilia, C. González-Artacho, M.J. Cabello-Tapia, P. de-la-TorreRubio, J. de-Teresa-Galván, Recurrent acute pancreatitis as clinical presentation of hydatid disease of the liver, Rev. Esp. Enferm. Dig. 104 (2012) 441-442, https:/ doi.org/10.4321/S1130-01082012000800011.

[30] O.O. Cakir, H. Ataseven, A. Demir, Hydatid acute pancreatitis, Turk. Parazitoloji Derg. 36 (2012) 251-253, https://doi.org/10.5152/tpd.2012.59.

[31] O. Ozcaglayan, A.M. Halefoglu, T. Ozcaglayan, H.A. Sumbul, Ultrasonographic diagnosis of acute pancreatitis caused by ruptured hydatid disease to the biliary system, JBRBTR 97 (2014) 33-35.

[32] A. Chaudhary, A.C. Upadhyaya, V.V. Kankanala, A. Kumar, N. Joshi, M. Kumar, Y. Harwani, R.P. Choudeswari, Intrabiliary rupture of hepatic hydatid cyst with impacted hydatid membranes at ampulla of Vater presenting as acute pancreatitis, Trop. Gastroenterol. 34 (2013) 43-44, https://doi.org/10.7869/tg.2012.93.

[33] W.H. Kitchens, C. Liu, E.T. Ryan, C. Fernandez-del Castillo, Hepatic hydatid cyst: a rare cause of recurrent pancreatitis, J. Gastrointest. Surg. 18 (2014) 2057-2059, https://doi.org/10.1007/s11605-014-2630-1.
[34] A. Belkouch, A. Mouhsine, Hydatid cyst ruptured in the biliary duct: an exceptional cause of acute pancreatitis, Pan Afr. Med. J. 18 (2014) 8688, https://doi.org/ 10.11604/pamj.2014.18.298.5147.

[35] A. Mahmoudi, K. Zouari, Une complication rare du kyste hydatique du foie: La pancréatite aiguë, Pan Afr. Med. J. 21 (2015) 8688, https://doi.org/10.11604/ pamj.2015.21.247.7600.

[36] H.E. Sikar, L. Kaptanoğlu, M. Kement, An unusual appearance of complicated hydatid cyst: necrotizing pancreatitis, Ulus, Travma ve Acil Cerrahi Derg. 23 (2017) 81-83, https://doi.org/10.5505/tjtes.2016.26820.

[37] B.S. Ahmad, A. Afzal, P. Ashraf, S.A. Abubakar, A. Munir, Manifestation of hydatid cyst of liver with pancreatitis, cholangitis and jaundice: a case report, J. Pakistan Med. Assoc. 68 (2018) 1097-1099.

[38] K and D, A. Bendjaballah, Acute recurrent pancreatitis secondary to biliary cystic fistula of liver hydatid cyst. An exceptional cause of, Ann. Clin. Case Rep. 4 (2019) $2-5$.

[39] N. Lahmidani, F.Z. Hamdoun, H. Abid, M. El Yousfi, D.A. Benajah, M. El Abkari, S. A. Ibrahimi, Acute pancreatitis as a rare complication of rupture of hydatid liver cyst: review of 16 cases, PAMJ Clin. Med. 1 (2019) 1-5, https://doi.org/10.11604/ pamj-cm.2019.1.17.20944.

[40] H.A. Gharbi, W. Hassine, M.W. Brauner, K. Dupuch, Ultrasound examination of the hydatic liver, Radiology 139 (1981) 459-463, https://doi.org/10.1148/ radiology.139.2.7220891.

[41] A. Zaouche, K. Haouet, M. Jouini, A. El Hachaichi, C. Dziri, Management of liver hydatid cysts with a large biliocystic fistula: multicenter retrospective study, World J. Surg. 25 (2001) 28-39, https://doi.org/10.1007/s002680020005. 